\title{
Peroxide Metabolism and Cold Hardiness in Apple Flower-buds during Spring Dehardening
}

\author{
Haruyuki Kuroda ${ }^{1}$, Shonosuke Sagisaka ${ }^{2}$ and Kazuhiko Chiba ${ }^{1}$ \\ 1 The Hokkaido National Agricultural Experiment Station, Sapporo 062 \\ 2 The Institute of Low Temperature Science, Hokkaido University, Sapporo 060
}

\begin{abstract}
Summary
The relationship between peroxide metabolism and cold hardiness in flower buds of the apple, Malus pumila Mill., was studied during natural spring dehardening and under controlled dehardening conditions. During the natural spring dehardening, there was an increase, as cold hardiness decreased, in the activities of NADH-Cyt $c$ reductase and Cyt $c$ oxidase, enzymes involved in the electron-transport chains that are a major site of production of $\mathrm{H}_{2} \mathrm{O}_{2}$. By contrast, the activities of glucose-6-phosphate dehydrogenase, glucosephosphate isomerase, glutathione reductase, glutathione peroxidase, dehydroascorbate reductase, and ascorbate peroxidase, enzymes associated with peroxide-scavenging systems that are coupled with the pentose phosphate cycle, varied as the development of flower buds proceeded. Under controlled dehardening conditions, the activities of NADH-Cyt $\mathrm{c}$ reductase and Cyt $\mathrm{c}$ oxidase increased while those of the enzymes associated with peroxide-scavenging systems that are coupled with the pentose phosphate cycle tended to decrease.

Both under natural and artificial dehardening conditions, the ratio of the activity of NADHCyt $\mathrm{c}$ reductase to that of glucose-6-phosphate dehydrogenase and the ratio of the activity of Cyt c oxidase to that of glucose-6-phosphate dehydrogenase, indices of oxidizability, increased as cold hardiness decreased. Thus, there was a significant correlation between the cold hardiness and the values of the oxidizability index. These results suggest that vernal decreases in cold hardiness may be interpreted as a process wherein the cells become susceptible to freezing injury due to oxidative stress.
\end{abstract}

\section{Introduction}

In a previous study we examined the relationship between cold hardiness and the ratio of the activity of NADH-Cyt $c$ reductase (NADH-CcR) to that of glucose-6-phosphate dehydrogenase (G6PDH) and the ratio of Cyt $c$ oxidase $(\mathrm{CcO})$ activity to that of $\mathrm{G} 6 \mathrm{PDH}$, as an index of cellular status representing susceptibility to oxidative stress (oxidizability index, OI), in twigs of the genus Malus in midwinter (Kuroda et al., 1991b). The cold hardiness of twigs in the species and cultivars examined decreased with increases in the value of OI in the xylem tissues. Since a higher value of OI implies a higher susceptibility of cells to oxidative stress, species or cultivars with high values of OI, such as $M$. halliana Koehne and M. pumila Mill. var.

Received for publication 16 March 1992. domestica Schneid. cv. Jonathan, may be particularly susceptible to freezing damage due to oxidative stress, with resultant low cold-hardiness. By contrast, species with low values of OI, such as $M$. baccata Borkh. and M. astracanica Dum., may be less sensitive to oxidative stress because of their high capacity for removal of peroxides. As a result, they exhibit high cold-hardiness. Thus, the differences in cold hardiness among woody species can be explained by differences in susceptibility to oxidative stress. Therefore, it is conceivable that seasonal changes in cold hardiness of woody species are also associated with increases and decreases in susceptibility to oxidative stress.

The purpose of this study was to examine the relationship between peroxide metabolism and cold hardiness of apple flower-buds during the spring. To this end, the changes in the cold hardiness and in the activities of enzymes associated with both 
peroxide-producing systems and peroxidescavenging systems were studied using flower buds collected in the field during natural spring dehardening and flower buds dehardened under controlled conditions. $\mathrm{NADH}-\mathrm{CcR}$ and $\mathrm{CcO}$ were chosen as enzymes that are involved in electrontransport chains related to peroxide-producing systems. The enzymes G6PDH, glucosephosphate isomerase (PGI), glutathione reductase (GSR), glutathione peroxidase (GSPOD), dehydroascorbate reductase (DHARD) and ascorbate peroxidase (AsAPOD) were chosen as enzymes associated with peroxide-scavenging systems that are coupled with the pentose phosphate cycle (pentose-P cycle). Catalase (CAT) was selected as an enzyme that catalyzes the removal of $\mathrm{H}_{2} \mathrm{O}_{2}$.

\section{Materials and Methods}

\section{Plant material}

Apple trees, Malus pumila Mill. var. domestica Schneid. cv. McIntosh, were grown at the Hokkaido National Agricultural Experiment Station. The flower buds on two-year-old twigs were collected from 2 February through 17 May 1987. The flower buds that were subjected to controlled dehardening conditions in the laboratory were collected on 20 February and stored in polyethylene bags at $-10^{\circ} \mathrm{C}$. They were used within one month.

\section{Evaluation of cold hardiness}

Two-year-old twigs with flower buds were placed in polyethylene bags and frozen at $-5^{\circ} \mathrm{C}$. They were then cooled in steps of $5^{\circ} \mathrm{C}$ at hourly intervals to successively lower temperatures. After standing at selected temperatures for $18 \mathrm{hr}$, the frozen samples were transferred to air at $5^{\circ} \mathrm{C}$. To evaluate the viability of flower buds after freezing, the lower parts of thawed twigs were kept in water in a greenhouse for two weeks. Thereafter, freezing injury was measured by the visual browning test as described previously (Kuroda et al., 1990). Fifteen flower-buds were used in each freezing test.

\section{Controlled dehardening}

For artificially dehardening of flower buds, the lower parts of the two-year-old twigs with flower buds were kept in water and then they were ex- posed to $25^{\circ} \mathrm{C}$, in dark incubator, for 1 to 2 days.

\section{Assay of water content}

Water content was determined by drying the samples at $100^{\circ} \mathrm{C}$ for $24 \mathrm{hr}$ and expressed as percentage of fresh weight.

\section{Assays of enzymes associated with peroxide- producing systems}

Homogenization mixtures consisted of $0.2 \mathrm{~g}$ of flower buds without bud scales, $0.3 \mathrm{~g}$ polyclar AT, $0.5 \mathrm{~g}$ sea sand, $1.0 \mathrm{ml}$ of a $2 \%$ solution of bovine serum albumin and $3.5 \mathrm{ml}$ of $0.05 \mathrm{M}$ Tris- $\mathrm{HCl}$ (pH 7.8) containing $0.25 \mathrm{M}$ sucrose and $2 \mathrm{mM}$ dithiothreitol. Grinding of the mixture was carried out with a mortar and pestle at $0^{\circ} \mathrm{C}$ and the homogenate was centrifuged at $300 \times \mathrm{g}$ for $10 \mathrm{~min}$ and then at $35,000 \times \mathrm{g}$ for $20 \mathrm{~min}$. The resultant pellet was suspended in $1 \mathrm{ml}$ of $0.05 \mathrm{M}$ Tris- $\mathrm{HCl}$ (pH 7.8) containing 0.25 M sucrose. Enzymatic activities (NADH-CcR and $\mathrm{CcO}$ ) were determined by conventional spectrophotometric methods as described previously (Sagisaka et al., 1989; Kuroda et al., 1991a).

\section{Assays of enzymes associated with peroxide- scavenging systems}

Homogenization mixtures consisted of $0.2 \mathrm{~g}$ of flower buds without bud scales, $0.3 \mathrm{~g}$ polyclar AT, $0.5 \mathrm{~g}$ sea sand, $1.0 \mathrm{ml}$ of a $2 \%$ solution of bovine serum albumin and $3.0 \mathrm{ml}$ of $0.05 \mathrm{M}$ Tris- $\mathrm{HCl}$ ( $\mathrm{pH} 7.8$ ) containing $2 \mathrm{mM}$ dithiothreitol. Grinding of the mixture and extraction of crude enzymes were carried out as described previously (Sagisaka, 1974). Enzymatic activities (G6PDH, PGI, GSR, GSPOD, DHARD, AsAPOD and CAT) were determined by conventional spectrophotometric methods as described previously (Sagisaka and Asada, 1981; Sagisaka, 1982, 1985; Nakagawara and Sagisaka, 1984).

\section{Results}

\section{Changes in the cold hardiness of flower buds in spring and under controlled dehardening conditions}

Fig. 1 shows the changes in cold hardiness and water content of flower buds in spring. Maximal hardiness was maintained until 2 March and buds survived freezing to $-30^{\circ} \mathrm{C}$. After the bud- 
swelling stage, cold hardiness decreased gradually as the air temperature rose, reaching $-5^{\circ} \mathrm{C}$ in late April immediately before the buds broke and $-3^{\circ} \mathrm{C}$ on 17 May at the time when buds start to show color. The water content increased from the bud-swelling stage to the leaf-expansion stage, and then it decreased slightly.

When hardy flower-buds were dehardened at $25^{\circ} \mathrm{C}$, they dehardened by as much as $10^{\circ} \mathrm{C}$ in one day. Also, artificial dehardening resulted in an in- crease in water content (Table 1).

2. Changes in the activities of enzymes associated with peroxide-producing systems in flower buds in spring and under controlled dehardening conditions

Fig. 2 shows the changes in the activities of $\mathrm{NADH}-\mathrm{CcR}$ and $\mathrm{CcO}$ in flower buds during the spring. The activity of NADH-CcR remained constant until March and then increased steadily,

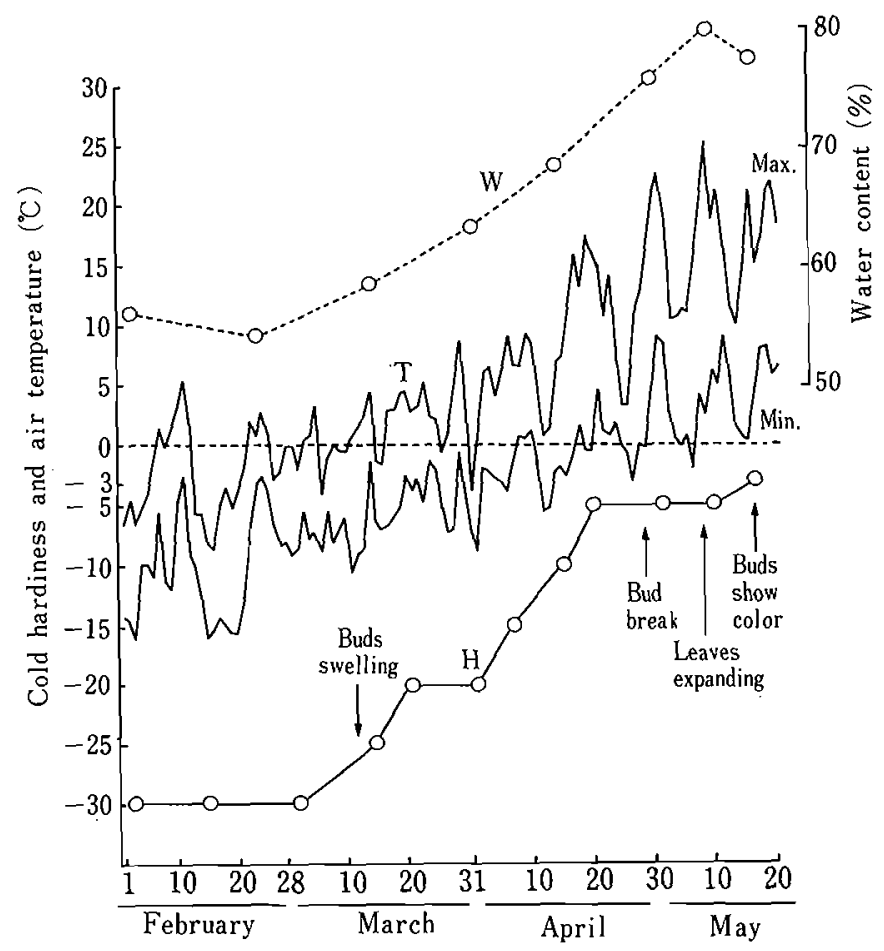

Fig. 1. Changes in cold hardiness and water content of apple flower-buds in the spring (1987), Cold hardiness is expressed as the minimum temperature at which the flower buds survive freezing without injury. $\mathrm{H}$, Cold hardiness; $W$, water content; $T$, air temperature.

Table 1. Effects of dehardening on the cold hardiness and water content of apple flower-buds.

\begin{tabular}{|c|c|c|c|c|c|c|c|}
\hline \multirow{2}{*}{$\begin{array}{l}\text { Duration of dehardening } \\
\text { (days) }\end{array}$} & \multicolumn{6}{|c|}{ Freezing temperature $\left({ }^{\circ} \mathrm{C}\right)$} & \multirow{2}{*}{$\begin{array}{c}\text { Water content }{ }^{*} \\
(\%)\end{array}$} \\
\hline & -5 & -10 & -15 & -20 & -25 & -30 & \\
\hline 0 & O & 0 & 0 & 0 & o & $\triangle$ & $56.4 \pm 0.5$ \\
\hline 1 & 0 & 0 & O & $\triangle$ & $\bullet$ & $\bullet$ & $59.1 \pm 1.6$ \\
\hline 2 & 0 & $\bullet$ & $\bullet$ & - & $\bullet$ & $\bullet$ & $65.5 \pm 1.4$ \\
\hline
\end{tabular}

Symbols: 0 , normal; $\triangle$, injured; $\bullet$, killed.

* Values represent means $\pm \mathrm{SE}$ of results from 3 separate experiments. 
reaching $496 \mu \mathrm{mol} \cdot \mathrm{g}^{-1} \mathrm{DW} \cdot \mathrm{hr}^{-1}$ on 16 May at the time when buds start to show color. The activity of $\mathrm{CcO}$ rose from February onwards, and by 16 May it had reached about 4 times the activity observed on 2 February.

In the flower buds dehardened at $25^{\circ} \mathrm{C}$, an increase in the activities of $\mathrm{NADH}-\mathrm{CcR}$ and $\mathrm{CcO}$ was also evident (Table 2).

\section{Changes in the activities of enzymes associated} with peroxide-scavenging systems in flower buds in spring and under controlled dehardening conditions

Fig. 3 shows the changes in the activities of G6PDH, PGI, GSR, GSPOD, DHARD, AsAPOD and CAT in flower buds during the spring. The activity of G6PDH remained unchanged in February, and then it decreased gradually until the stage at which buds broke. Thereafter, the activity increased abruptly and then decreased again after the leaves had expanded. The changes in activity of PGI, GSR and DHARD exhibited an identical pattern to that of G6PDH. The pattern in the rise

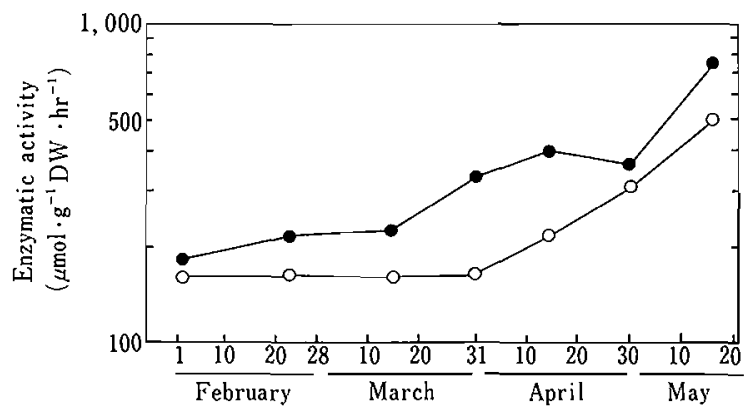

Fig. 2. Changes in activities of NADH-Cyt $c$ reductase and Cyt c oxidase associated with peroxide-producing systems in apple flower-buds during spring dehardening. $\mathrm{O}, \mathrm{NADH}-\mathrm{Cyt}$ $c$ reductase; $\bullet$, Cyt $\mathrm{c}$ oxidase. and fall of the activity of GSPOD was also similar to that of G6PDH, although the enzyme exhibited very low levels of activity after the stage at which buds broke. AsAPOD activity increased from early April to the leaf-expansion stage, and then it declined simultaneously with the decline in activities of the above-mentioned enzymes. The activity of CAT was lowest in late March and then continued to increase as the development of flower buds proceeded.

During dehardening at $25^{\circ} \mathrm{C}$, the changes in activities of enzymes in the peroxide scavengingsystems that are coupled with the pentose-P cycle did not coincide with those observed in buds in the natural environment. The activities of $\mathrm{G} 6 \mathrm{PDH}$, PGI, GSR, GSPOD, DHARD and AsAPOD were observed to decrease, while that of CAT tended to increase (Table 3).

4. Relationship between cold hardiness and the index of susceptibility of cells to oxidative stress (oxidizability index, OI)

The OI was expressed as:

$\mathrm{OI}=$ Activity of $\mathrm{NADH}-\mathrm{CcR}$ or $\mathrm{CcO} /$ Activity of G6PDH

Fig. 4 shows the changes in the values of $\mathrm{OI}$ of apple flower-buds during the natural spring dehardening, as related to the cold hardiness. The changes in the values of OI of flower buds that were dehardened under controlled conditions are shown in Fig. 5. Both under natural and artificial dehardening conditions, the ratio of the activity of NADH-CcR to that of G6PDH and the ratio of the activity of $\mathrm{CcO}$ to that of $\mathrm{G} 6 \mathrm{PDH}$ increased as cold hardiness decreased, demonstrating a close relationship between cold hardiness and the OI.

When we examined the correlation between cold hardiness and the ratio of the activity of $\mathrm{NADH}$ -

Table 2. Effects of dehardening on the activities of NADH-Cyt $c$ reductase and $C_{y} t c$ oxidase associated with peroxide-producing systems in apple flower-buds.

\begin{tabular}{lccc}
\hline \hline \multirow{2}{*}{ Enzyme } & \multicolumn{3}{c}{ Duration of dehardening (days) } \\
\cline { 2 - 3 } & 0 & \multicolumn{3}{c}{1} & 2 \\
\hline NADH-Cyt c reductase & $161 \pm 8.8$ & $\left.\mathbf{m o l} \cdot \mathrm{g}^{-1} \mathrm{DW} \cdot \mathrm{hr}^{-1}\right)$ \\
Cyt c oxidase & $232 \pm 9.1$ & $264 \pm 9.1$ & $227 \pm 9.6$ \\
\hline
\end{tabular}

Values represent means $\pm \mathrm{SE}$ of results from 3 separate experiments. 


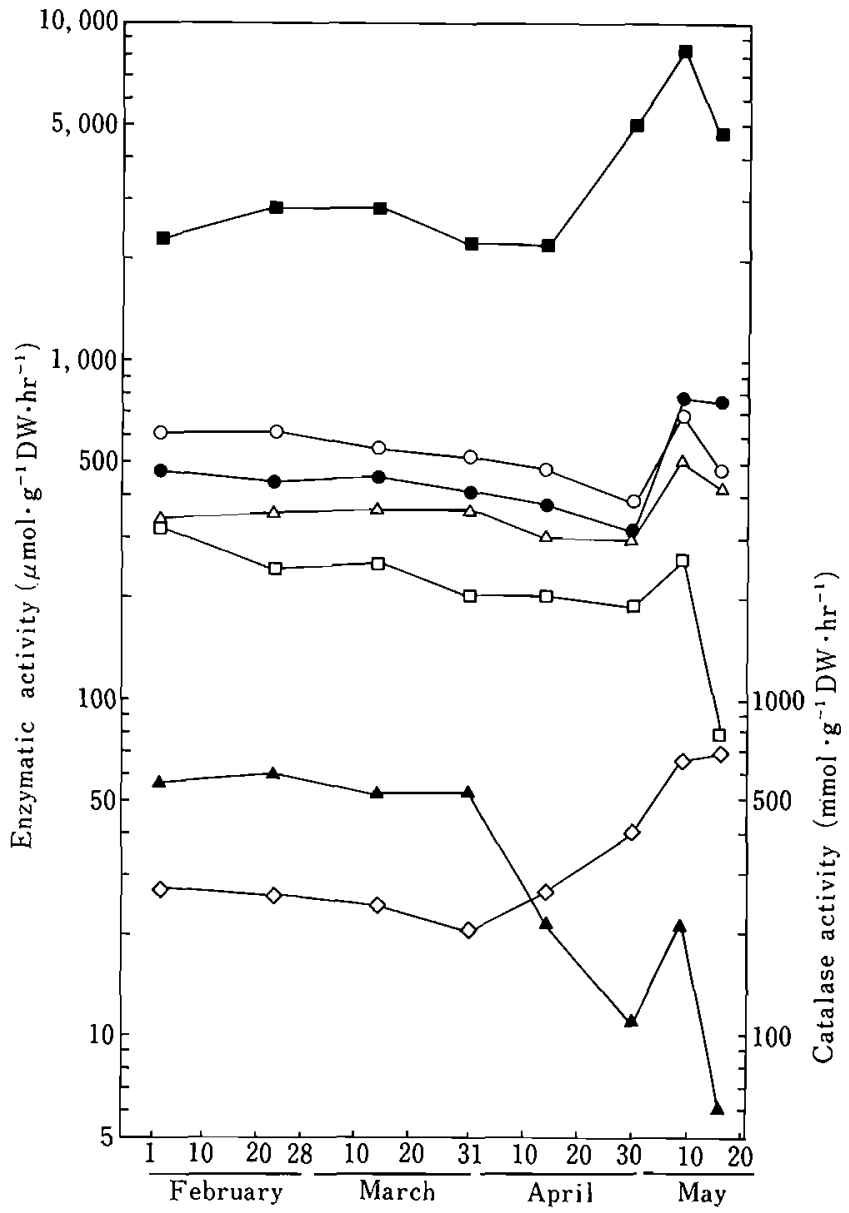

Fig. 3. Changes in activities of enzymes associated with peroxidescavenging systems in apple flower-buds during spring dehardening. $\circ$, Glucose-6-phosphate dehydrogenase; $\bullet$, glucosephosphate isomerase; $\Delta$, glutathione reductase; $\boldsymbol{\Lambda}$, glutathione peroxidase; $\square$, dehydroascorbate reductase; $\boldsymbol{\bullet}$, ascorbate peroxidase; $\diamond$, catalase.

Table 3. Effects of dehardening on the activities of enzymes associated with peroxide-scavenging systems in apple flower-buds.

\begin{tabular}{lccc}
\hline \hline \multirow{2}{*}{ Enzyme } & \multicolumn{4}{c}{ Duration of dehardening (days) } \\
\cline { 2 - 5 } & 0 & \multicolumn{4}{c}{1} & 2 \\
\hline Glucose-6-phosphate dehydrogenase & $575 \pm 40.4$ & $421 \pm 38.5$ & $281 \pm 22.2$ \\
Glucosephosphate isomerase & $455 \pm 28.7$ & $479 \pm 30.6$ & $402 \pm 20.2$ \\
Glutathione reductase & $266 \pm 11.8$ & $249 \pm 10.7$ & $183 \pm 11.6$ \\
Glutathione peroxidase & $55 \pm 3.0$ & $48 \pm 2.5$ & $40 \pm 2.8$ \\
Dehydroascorbate reductase & $193 \pm 10.2$ & $193 \pm 10.8$ & $138 \pm 8.3$ \\
Ascorbate peroxidase & $2,670 \pm 142$ & $2,476 \pm 136$ & $2,223 \pm 143$ \\
Catalase $^{2}$ & $177 \pm 13$ & $155 \pm 13$ & $225 \pm 18$ \\
\hline
\end{tabular}

Values represent means $\pm \mathrm{SE}$ of results from 3 separate experiments.

" $\mathrm{mmol} \cdot \mathrm{g}^{-1} \mathrm{DW} \cdot \mathrm{hr}^{-1}$. 


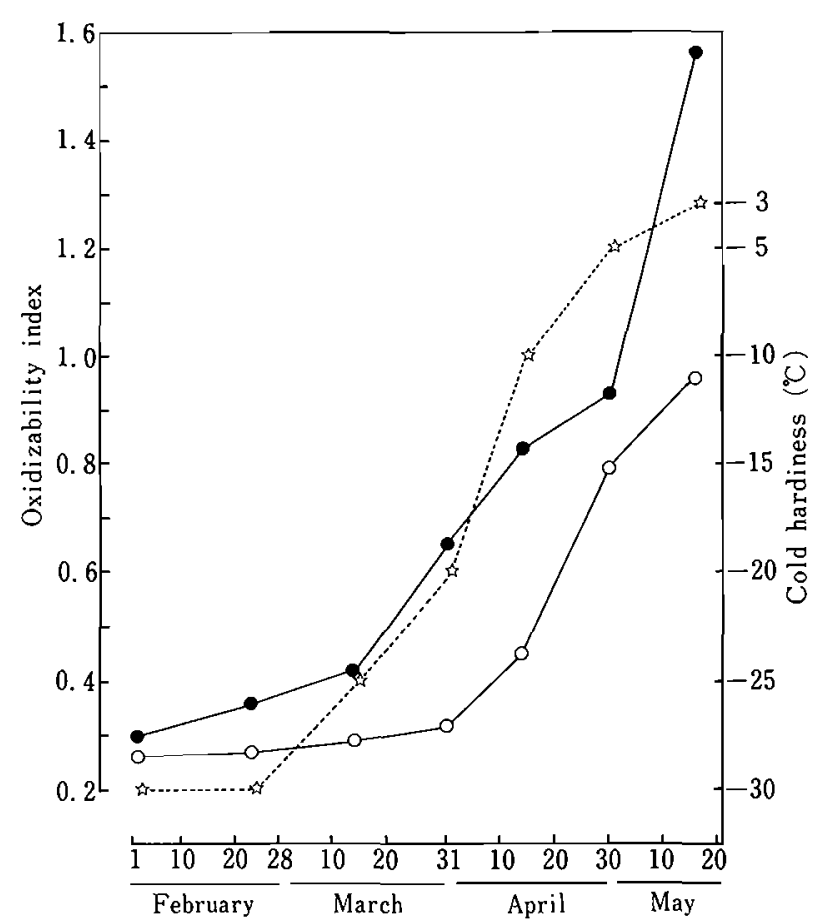

Fig. 4. Relationship between cold hardiness and the oxidizability index in apple flower-buds during spring dehardening. $O$, Ratio of NADHCyt $\mathrm{c}$ reductase activity to glucose-6-phosphate dehydrogenase activity; - ratio of Cyt $c$ oxidase activity to glucose-6-phosphate dehydrogenase activity; is, cold hardiness.

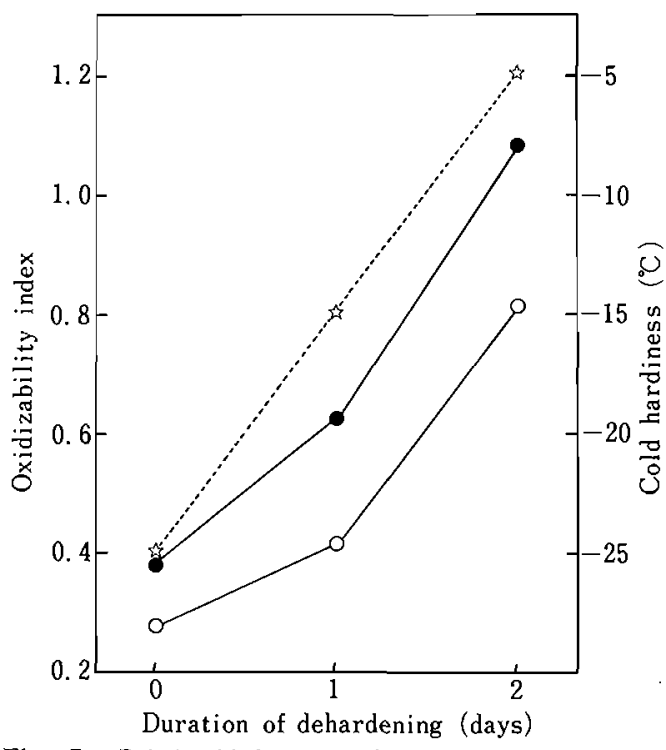

Fig. 5. Relationship between cold hardiness and the oxidizability index in apple flower-buds subjected to controlled dehardening. Symbols are explained in the legend to Fig. 4.
$\mathrm{CcR}$ to that of G6PDH and the ratio of the activity of $\mathrm{CCO}$ to that of $\mathrm{G} 6 \mathrm{PDH}$, high positive correlation coefficients, namely, $r=+0.954^{* *}$ and $r=+0.965^{* *}$, respectively, were obtained (Table 4). The same result was found when flower buds were dehardened at $25^{\circ} \mathrm{C}$, and a high correlation was found between cold hardiness and the OI. No correlation was found between cold hardiness and the values obtained when calculations were made with CAT activity instead of G6PDH activity.

\section{Discussion}

During the spring, the activities of NADH-CcR and $\mathrm{CcO}$ in the electron-transport chains, a major site of production of $\mathrm{H}_{2} \mathrm{O}_{2}$, increased as cold hardiness of apple flower-buds decreased. The activity of these two enzymes increased when the buds were exposed to dehardening conditions at $25^{\circ} \mathrm{C}$. This observation suggests that there is a close relationship between the deacclimation and the increase in the activities of NADH-CcR and $\mathrm{CcO}$. However, it has also been found that the activities of $\mathrm{NADH}-\mathrm{CcR}$ and $\mathrm{CcO}$ increase as twigs 
Table 4. Correlation coefficients for the relationship between cold hardiness and the oxidizability index for apple flowerbuds during natural spring dehardening and under artificial dehardening conditions.

\begin{tabular}{lcc}
\hline Condition & Correlation coefficient ( $\mathrm{r})$ \\
\cline { 2 - 4 } & Cold hardiness vs. NADH-CcR activity/ G6PDH activity & Cold hardiness vs. CcO activity/ G6PDH activity \\
\hline Natural & $+0.954^{* *}$ & $+0.965^{* *}$ \\
Artificial & $+0.991^{* *}$ & $+0.998^{* *}$ \\
\hline
\end{tabular}

** Significant at the $1 \%$ level.

For complete list of abbreviations, see Introduction.

become acclimatized to the autumn and winter cold (Kuroda et al., 1991a). It is, therefore, difficult to explain a direct relationship between the increases in the activities of enzymes in the electrontransport chains and the deacclimation in spring.

The increase in the enzymatic activity in the electron-transport chains results in higher rates of production of $\mathrm{H}_{2} \mathrm{O}_{2}$ (Chance et al., 1979; Elstner, 1982). It has been found that the $\mathrm{H}_{2} \mathrm{O}_{2}$ produced non-enzymatically in non-photosynthetic tissues is removed via the peroxide-scavenging systems that are coupled with the pentose-P cycle (Nakagawara and Sagisaka, 1984; Kuroda et al., 1990). In the present study, however, the changes in activities of the enzymes associated with these peroxidescavenging systems exhibited a different pattern to those of the enzymes in the electron-transport chains. Namely, the activity of enzymes associated with peroxide-scavenging systems that are coupled with the pentose-P cycle, varied as the development of flower buds proceeded. Under controlled dehardening conditions, the activity of these enzymes tended to decrease. Since the activity of systems for scavenging $\mathrm{H}_{2} \mathrm{O}_{2}$ should balance its rate of production, this imbalance between the enzymatic activities of the peroxide-scavenging systems and the electron-transport chains can be considered to influence cold hardiness of trees.

In our previous study we demonstrated that the cold hardiness of twigs of the genus Malus in midwinter is closely related to the OI of xylem tissues (Kuroda et al., 1991b). In the present experiments we also obtained a high correlation between cold hardiness and the ratio of the activity of NADH$\mathrm{CcR}$ to that of G6PDH or the ratio of the activity of $\mathrm{C} C \mathrm{O}$ to that of $\mathrm{G} 6 \mathrm{PDH}$, both in nature and under artificial dehardening conditions, and we found a close relationship between a decrease in cold hardiness and an increase in the OI. A higher value of $\mathrm{OI}$ is associated with lower activities of enzymes that eliminate $\mathrm{H}_{2} \mathrm{O}_{2}$ as compared with the rate of production of $\mathrm{H}_{2} \mathrm{O}_{2}$, which in turn implies a higher susceptibility of the cells to oxidative stress. The vernal decrease in cold hardiness of the flower buds may, therefore, be interpreted as a process wherein the cells become susceptible to freezing damage due to oxidative stress.

Environmental stress, such as chilling (Wise and Naylor, 1987), sunscald (Rabinowitch and Sklan, 1980), heavy metals (Sandmann and Böger, 1980), ozone (Sakaki et al., 1983) and $\mathrm{SO}_{2}$ (Shimazaki et al., 1980), increases the production of active oxygen in plants. The reactions of active oxygen with cellular components, such as proteins (Charles and Halliwell, 1980; Tanaka et al., 1982), lipids (Shimazaki et al., 1980; Fridovich and Porter, 1981) and DNA (Brawn and Fridovich, 1981; Lesko et al., 1980), cause critical cellular dysfunctions that result in cell death. Sagisaka (1985, 1986) described the process involved in the death of poplar twigs in the frozen state: a decrease in the ability to remove peroxide occurs in the twigs, with resultant inactivation of some enzymes and the formation of lipid hydroperoxides in cellular membranes, and the twigs die. These observations indicate that when the rate of production of reducing power, such as that of NADPH and glutathione, becomes lower than that of the active oxygen species, cells turn brown and are no longer able to survive. The results of the present study raise the possibility that freezing damage is brought about by active oxygen species.

\section{Literature Cited}

Brawn, K. and I. Fridovich. 1981. DNA strand scission by enzymically generated oxygen radicals. Arch. $\mathrm{Bi}$ ochem. Biophys. 206 : 414-419.

Chance, B., H. Sies and A. Boveris. 1979. Hydroperoxide metabolism in mammalian organs. Physiol. Rev. $59: 527-605$. 
Charles, S. A. and B. Halliwell. 1980. Effect of hydrogen peroxide on spinach (Spinacia oleracea) chloroplast fructose bisphosphatase. Biochem. J. $189: 373-376$.

Elstner, E.F. 1982. Oxygen activation and oxygen toxicity. Ann. Rev. Plant Physiol. 33: 73-96.

Fridovich, S.E. and N.A. Porter. 1981. Oxidation of arachidonic acid in micelles by superoxide and hydrogen peroxide. J. Biol. Chem. 256 : 260-265.

Kuroda, H., S. Sagisaka and K. Chiba. 1990. Seasonal changes in peroxide-scavenging systems of apple trees in relation to cold hardiness. J. Japan. Soc. Hort. Sci. 59 : 399-408.

Kuroda, H., S. Sagisaka, M. Asada and K. Chiba. 1991a. Seasonal variation in the activities of $\mathrm{NADH}$-cytochrome $\mathrm{c}$ reductase and cytochrome $\mathrm{c}$ oxidase in plastids, mitochondria and microsomes in apple trees. J. Japan. Soc. Hort. Sci. 60:457-466.

Kuroda, H., S. Sagisaka and K. Chiba. 1991b. Cold hardiness and peroxide metabolism in the genus $\mathrm{Ma}$ lus in midwinter. J. Japan. Soc. Hort. Sci. $60: 719-728$. (In Japanese with English summary).

Lesko, S.A., R.J. Lorentzen and P.O.P. Ts'o. 1980. Role of superoxide in deoxyribonucleic acid strand scission. Biochemistry 19:3023-3028.

Nakagawara, S. and S. Sagisaka. 1984. Increase in enzyme activities related to ascorbate metabolism during cold acclimation in poplar twigs. Plant Cell Physiol. 25 : 899-906.

Rabinowitch, H.D. and D. Sklan. 1980. Superoxide dismutase: A possible protective agent against sunscald in tomatoes (Lycopersicon esculentum Mill.). Planta $148: 162-167$.

Sagisaka, S. 1974. Transition of metabolisms in living poplar bark from growing to wintering stages and vice versa. Plant Physiol. 54 : 544-549.

Sagisaka, S. and M. Asada. 1981. Coordinate and noncoordinate changes in enzyme activities in pentose phosphate cycle in poplar: A control of enzyme activities in differentiated xylem. Plant Cell Physiol. 22 : $1459-1468$.

Sagisaka, S. 1982. Comparative studies on the metabolic function of differentiated xylem and living bark of wintering perennials. Plant Cell Physiol. 23 : $1337-1346$.

Sagisaka, S. 1985. Injuries of cold acclimatized poplar twigs resulting from enzyme inactivation and substrate depression during frozen storage at ambient temperatures for a long period. Plant Cell Physiol. $26: 1135-1145$.

Sagisaka, S. 1986. Limited survival period of cold acclimatized trees in frozen ambient temperatures. Plant Cell Physiol. 27 : 1209-1212.

Sagisaka, S., M. Asada and H. Kuroda. 1989. Dormancy breaking is followed by mitochondria proliferation in poplar and apple trees in milieu of midwinter. Plant Cell Physiol. 30:79-84.

Sakaki, T., N. Kondo and K. Sugahara. 1983. Breakdown of photosynthetic pigments and lipids in spinach leaves with ozone fumigation: Role of active oxygens. Physiol. Plant. $59: 28-34$.

Sandmann, G. and P. Böger. 1980. Copper-mediated lipid peroxidation processes in photosynthetic membranes. Plant Physiol. $66: 797-800$.

Shimazaki, K., T. Sakaki, N. Kondo and K. Sugahara. 1980. Active oxygen participation in chlorophyll destruction and lipid peroxidation in $\mathrm{SO}_{2}$-fumigated leaves of spinach. Plant Cell Physiol. 21 : 1193-1204.

Tanaka, K., T. Otsubo and N. Kondo. 1982. Participation of hydrogen peroxide in the inactivation of Calvin-cycle $\mathrm{SH}$ enzymes in $\mathrm{SO}_{2}$-fumigated spinach leaves. Plant Cell Physiol. 23 : 1009-1018.

Wise, R.R. and A.W. Naylor. 1987. Chilling-enhanced photooxidation. Evidence for the role of singlet oxygen and superoxide in the breakdown of pigments and endogenous antioxidants. Plant Physiol. $83: 278-282$. 
リンゴ花芽の春における耐凍性変動と過酸化物代謝

黑田治之 ${ }^{1} \cdot$ 匂坂勝之助 ${ }^{2} \cdot$ 千葉和彦 1

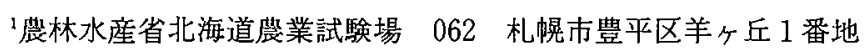

${ }^{2}$ 北海道大学低温科学研究所 060 札幌市北区北19条西 8 丁目

\begin{abstract}
摘要
リンゴ花芽の春における耐凍性変動と過酸化物代謝 の関係を検討するために，自然および人為的デハード ニング条件下における耐凍性ならびに過酸化物の生成 系と分解系の代謝活性を調べた. 自然条件下において, 過酸化物生成系である電子伝達系の NADH-Cyt c 還元 酵素と Cyt c 酸化酵素活性はいずれも耐凍性の減少に 伴って増加した。一方, 五炭糖リン酸回路に共役した 過酸化物分解系のグルコース-6-リン酸脱水素, ホスホ グルコースイソメラーゼ, グルタチオン僈元酵素, グ ルタチオンペルキシダーゼ, デヒドロアスコルビン酸 還元酵素抢よびアスコルビン酸ペルオキシダーゼ活性 は花莱の発育に伴って夜動し, 電子伝達系の酵素活性 の変化と異なったパターンを示した．人為的デハード

素とCyt c 酸化酵素活性はいずれも増加したが, 五炭 糖りン酸回路に共役した過酸化物分解系の酵素活性は 低下し，西者は正逆関係を示した。

酸化的ストレスの受けやす巳を示す指標 (Oxidizability Index, OI) としての NADH-Cyt $\mathrm{c}$ 䑟元酵素 活性/グルコース-6-リン酸脱水素酵素活性比あるいは Cyt c 酸化酵素活性ノグルコースー6-リン酸脱水素酵素 活性比は，自然および人為的デハードニングの而条件 下に扔いて耐凍性減少に伴って増加することが認めら れ, OI 值と耐凍性との間には高い相関係数が得られた。 この上うな結果から, 春における耐凍性減少は過酸化 物代謝に伴う酸化的ストレスの高まりと密接に関係し ているものと考えられる。
\end{abstract} ニング条件下では, 電子伝達系の NADH-Cyt c 薑元酵 